\title{
Anbefalt nordisk kosthold og risikomarkører for hjerte- og karsykdom
}

\begin{abstract}
BAKGRUNN Hjerte- og karsykdommer er blant de ledende årsakene til sykelighet og dødelighet i Norge. Formålet med denne artikkelen er å gi en oversikt over litteratur som omhandler effekten av et nordisk kosthold i tråd med myndighetenes kostholdsråd på risikofaktorer for hjerte- og karsykdom.
\end{abstract}

KUNNSKAPSGRUNNLAG Litteratursøk ble gjort elektronisk i databasene PubMed, Cochrane og Embase. Randomiserte, kontrollerte studier som omhandlet nordisk kosthold og hjerte- og karsykdom ble inkludert. Totalt 15 artikler ble inkludert. Disse er basert på fire kostintervensjonsstudier som er utført i Norden.

RESULTATER Alle kostintervensjonsstudiene viste effekter på blodlipider. I en av studiene førte nordisk kosthold til en reduksjon i LDL-kolesterolnivå på $21 \%$. Tre av studiene viste at et nordisk kosthold reduserer blodtrykket. Resultater fra to av studiene viste at det også forbedret glukose- og insulinsensitiviteten, men etter justering for vekttap ble denne effekten borte. I tre av studiene ble det vist at et nordisk kosthold kan påvirke inflammasjon i en gunstig retning.

FORTOLKNING Et kosthold basert på myndighetenes kostråd og bestående av nordiske råvarer gir bedre risikoprofil hos dem som er disponert for å utvikle hjerte- og karsykdom.

Hjerte- og karsykdommer er en ledende årsak til sykelighet og dødelighet globalt og i Norge $(1,2)$. Det er godt dokumentert at middelhavskostholdet forebygger utvikling av disse sykdommene (3-5). Middelhavskostholdet er karakterisert av et høyt inntak av frukt, belgfrukter, grønnsaker, olivenolje, kornprodukter og nøtter og et moderat inntak av fisk, magre meieriprodukter og rødvin samt et lavt inntak av rødt kjøtt (6).

Det kan imidlertid diskuteres om én type regionalt kosthold bør anbefales verden over - på grunn av kostnader, begrenset tilgang til aktuelle råvarer og kulturelle forskjeller i spisevaner (7-9). Hva slags mat vi spiser, har stor innvirkning på miljøet, da mye fødevarer fraktes over store distanser (10). For å ta høyde for regionale forskjeller med hensyn til matkultur, vekstvilkår og bærekraft har man foreslått et sunt nordisk kosthold som alternativ til middelhavskostholdet (11).

Denne kosten består av ingredienser vi finner i Norden - bær, kål, fisk og sjømat, magert viltkjøtt, rapsolje og kornsortene havre, rug og bygg, som alle inngår i myndighetenes kostråd (12). Denne oversiktsartikkelen omhandler hvilken effekt et nordisk kosthold med regionale matvarer har på risikofaktorer for hjerte- og karsykdom.

\section{Kunnskapsgrunnlag}

8.8. 2016 gjorde vi søk i databasene PubMed, Cochrane og Embase. Søkeordene «Nordic diet AND health effects» ga totalt 98 treff -83 etter fjerning av duplikater (fig 1). Etter eksklusjon av de artiklene som ikke omhandlet helseeffekter av et nordisk kosthold, gjensto det 23 , hvorav det i 12 var rapportert resultater fra randomiserte, kontrollerte studier som omhandlet hjerte- og karsykdom hos voksne. I tillegg ble det inkludert tre artikler som omhandlet helseeffekter av viktige nordiske matvarer, men som ikke kom opp i søket.

Til sammen inngår 15 artikler i denne oppsummeringen. Det ble ikke satt tidsavgrensning for publikasjonsår, men søkene ble begrenset til humane studier og fulltekstartikler (ikke konferansebidrag). I PubMed ble det søkt etter artikler på norsk, dansk, svensk og engelsk. Det ble ikke satt noen språkavgrensning i Cochrane Library eller Embase.

De 15 artiklene (13-27) som ble inkludert, er basert på fire randomiserte, kontrollerte kostintervensjonsstudier (tab 1) (13, $15,18,19,28,29)$. Disse studiene er gjort $\mathrm{i}$ Sverige (NORDIET), med personer med moderat forhøyet kolesterolnivå, i Danmark (New Nordic Diet, NND), med overvektige, i Finland (SYSDIMET), med moderat overvektige med nedsatt glukosemetabolisme. Til sist er det en felles nordisk intervensjonsstudie (SYSDIET), gjennomført i Finland, Sverige, Danmark og Island med personer med metabolsk syndrom.

Til sammen 600 personer ble randomisert og 505 fullførte intervensjonsstudiene, som varte i 6-26 uker. Det var størst frafall i SYSDIET- og NND-studien, til sammen 34 deltagere $i$ hver av disse falt fra. I SYSDIETstudien var det størst frafall i kontrollgruppen $(\mathrm{n}=26)$, i NND-studien var det størst frafall $\mathrm{i}$ gruppen med nordisk kosthold $(\mathrm{n}=22)$. I SYSDIMET-studien var det 25 personer som falt fra, likt fordelt mellom

\section{Astrid Berild}

Avdeling for ernæringsvitenskap Institutt for medisinske basalfag Universitetet i Oslo

Kirsten B. Holven

Avdeling for ernæringsvitenskap Institutt for medisinske basalfag Universitetet i Oslo og

Nasjonal kompetansetjeneste for familiær hyperkolesterolemi

Avdeling for endokrinologi, sykelige overvekt og preventiv medisin

Oslo universitetssykehus, Rikshospitalet

\section{Stine M. Ulven}

smulven@medisin.uio.no

Avdeling for ernæringsvitenskap

Institutt for medisinske basalfag

Universitetet i Oslo

Kirsten B. Holven og Stine M. Ulven var veiledere for Astrid Berild i hennes prosjektoppgave ved medisinstudiet ved Universitetet i Oslo.

IL Engelsk oversettelse på www.tidsskriftet.no

\section{HOVEDBUDSKAP}

Et nordisk kosthold i henhold til anbefalingene forbedrer lipidprofilen

Et sunt nordisk kosthold har gunstig effekt på blodtrykket

Et sunt nordisk kosthold kan ha en gunstig effekt på inflammasjon 


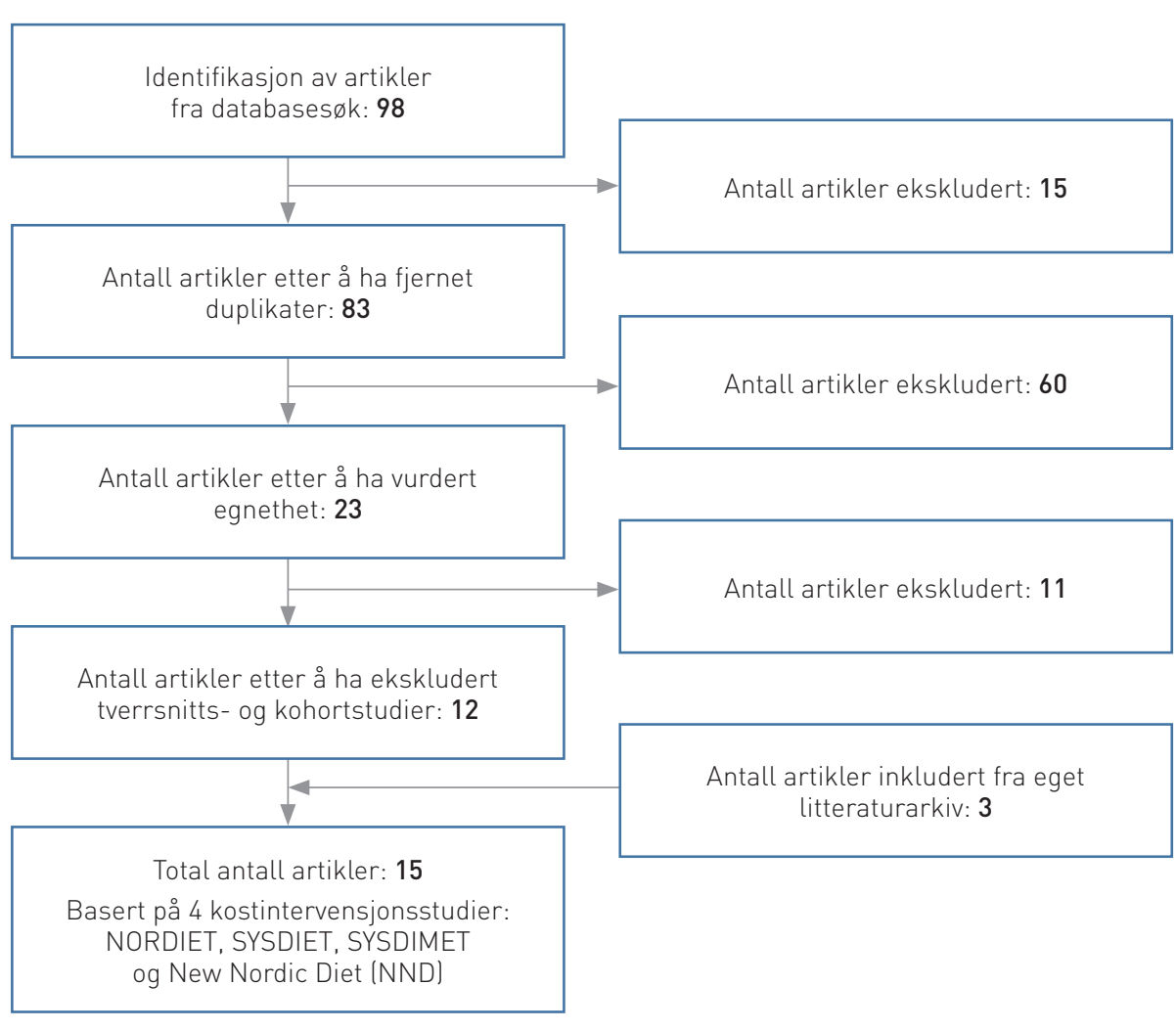

Figur 1 Prosedyre for utvelgelse av artikler etter søk i databasene PubMed, Cochrane og Embase med søkeordene "Nordic diet AND health effects»

gruppene. I NORDIET-studien var det én fra hver gruppe som falt fra. Frafallsårsakene var forskjellige, de viktigeste var vanskeligheter med å spise maten, mangel på motivasjon og mangel på tid.

\section{Lipider}

I alle kostintervensjonsstudiene ble det påvist effekt av nordisk kosthold på blodlipidene.

I NORDIET-studien (tab 1) ble totalkolesterolnivået redusert med $0,98 \mathrm{mmol} / 1 \mathrm{og}$ LDL-kolesterolnivået med $0,83 \mathrm{mmol} / 1$ i gruppen som spiste nordisk kost. I kontrollgruppen var det en økning på $0,23 \mathrm{mmol} / \mathrm{l}$ i totalkolesterolnivå og en økning på $0,10 \mathrm{mmol} /$ 1 i LDL-kolesterolnivå. Endringene var signifikant forskjellig i de to gruppene (henholdsvis $\mathrm{p}<0,0001$ og $\mathrm{p}<0,001$ ) (13). I utgangspunktet var kostholdet mer eller mindre likt. Det var reduksjonen i serumnivået av de mettete fettsyrene C14:0, C15:0 og C18:0 og økningen av den flerumettede omega-3-fettsyren $22: 6, \mathrm{n}-3$ som var relatert til forbedringen av lipidprofilen (22).

I SYSDIET-studien (tab 1) ble ikke-HDLkolesterolnivået redusert med henholdsvis $0,22 \mathrm{mmol} / \mathrm{l}$ og $0,06 \mathrm{mmol} / \mathrm{l}$ for dem som spiste nordisk kost og for kontrollgruppen. Endringen var signifikant forskjellig $i$ de to gruppene $(p=0,04)(15)$. er klinisk relevant, og virkningen er stor med tanke på at kostholdet består av mange komponenter som har biologiske effekter.

Den kraftige reduksjonen i LDL-kolesterolnivå i NORDIET-studien kan skyldes at inntaket av mettet fett ble redusert fra 14 energiprosent til 5 energiprosent i gruppen med nordisk kosthold, i tillegg til økt inntak av fiber, i tråd med tidligere studier (31). En slik endring i inntaket av mettet fett kan være vanskelig å få til uten at deltagerne får utlevert all mat de skal spise.

I SYSDIET-studien, der man ga deltagerne råd om å bytte ut matvarer eller redusere inntaket av enkelte produkter, ble endringen $\mathrm{i}$ inntaket av mettet fett mindre enn $\mathrm{i}$ NORDIET-studien. I etterkant av SYSDIETstudien ble det gjort analyser av deltagernes kosthold basert på biomarkører i blod knyttet til inntak av fet fisk, grønnsaker, fullkorn og linfrøolje. De som ut fra biomarkørnivåene i blodet hadde høyest etterlevelse, fikk en mer gunstig effekt på total- og LDL-kolesterolnivået (24).

Dette styrker funnene om at jo bedre man etterlever kostholdsrådene, desto større er risikoreduksjon for hjerte- og karsykdom. I tillegg ble det observert en signifikant endring $\mathrm{i}$ plasma-lipidomprofilen (alle typer lipidmetabolitter i plasma) mellom gruppene i SYSDIET-studien (25). Profilering av alle lipider i blodet kan mer sensitivt registrere metabolske endringer og spesifikke lipidmetabolitter knyttet til risiko for sykdom (33). I SYSDIET-studien økte nivået av metabolitter (plasmalogener) med antioksidative egenskaper, og nivået av metabolitter (ceramider) som er knyttet til utvikling av insulinresistens, ble redusert $\mathrm{i}$ gruppen med nordisk kosthold (25). Det er usikkert hva disse resultatene betyr.

I SYSDIMET-studien (tab 1) var økt inntak av fisk assosiert med en økning i store HDL-partikler (17). NORDIET-studien ble HDL-kolesterolnivået redusert med 0,08 $\mathrm{mmol} / \mathrm{l}$ i gruppen med nordisk kosthold, mens det økte med $0,11 \mathrm{mmol} / 1$ i kontrollgruppen. Effekten var signifikant forskjellig $\mathrm{i}$ de to gruppene $(p=0,001)(13)$. I SYSDIETog NND-studien ble ikke HDL-kolesterolnivået signifikant endret $(15,18)$.

HDL-kolesterolnivåets betydning for risikoen for hjerte- og karsykdom er ikke avklart. Selv om observasjonsstudier har vist at høyt nivå av HDL-kolesterol er assosiert med mindre risiko for hjerte- og karsykdom (34), er den kliniske betydningen av reduksjon $\mathrm{i}$ HDL-kolesterolnivået ukjent, da det i studier med legemidler som øker HDL-kolesterolnivået ikke har vært reduksjon i hjerte- og karsykdom $(35,36)$. Sammenlignet med den positive effekten av redusert total- og LDLkolesterolnivå spiller den lille reduksjonen i HDL-kolesterolnivå sannsynligvis mindre rolle for risikoen for hjerte- og karsykdom. 
Tabell 1 Oversikt over kostholdet i intervensjonsstudiene

Studie

NORDIETstudien (13)

SYSDIET-

studien (15)

New Nordic

Diet (NND)

studien (18)

SYSDIMETstudien (19)

\section{Gruppen med sunt nordisk kosthold}

All maten ble utlevert til deltagerne og alle måltider med unntak av frokost, var laget ferdig. Næringsstoffene i menyen var basert på de nordiske kostholdsanbefalingene. Matvarene skulle være tilgjengelig i butikk og $80 \%$ av maten skulle kunne dyrkes i Norden (28). Maten skulle spises ad libitum

Kornprodukter: Fullkorn i kornblandinger, brød, grøt og pasta (rug, bygg og havre)

Grønnsaker, frukt, bær: Rotgrønnsaker, epler, pærer, blåbær og tyttebær

Matfett: vegetabilsk rapsolje/solsikkeolje/linfrøolje (38\% fett) uten tilsatte plantesteroler til brødskiver, flytende vegetabilsk rapsolje-/solsikkeolje-/linfrøoljemargariner til matlaging (80\% fett). Rapsolje til dressinger

Meieriprodukter: Magre meieriprodukter og ost ( $\leq 17 \%$ fett) Fisk: Fet fisk (laks, makrell, sild)

Kjøtt: Kylling, oksekjøtt, svinekjøtt, lam og reinsdyr

Drikke: vanlig alkoholinntak, vann, te, kaffe, jus av frukt og grønnsaker, alkoholfritt øl

Kostholdet var basert på de nordiske kostholdsanbefalingene. Det ble gitt råd om hva deltagerne skulle spise, og enkelte produkter ble utdelt. Isokalorisk kosthold

Kornprodukter: $\geq 25 \%$ av total energi skulle komme fra fullkornprodukter lav disse skal $\geq 50 \%$ være fra rug, bygg og havre). Fullkorn pasta og ris ( $\geq 6 \mathrm{~g}$ fiber $/ 100 \mathrm{gl} \geq 2-3$ måltider/uke. Brød ( $\geq 6 \mathrm{~g}$ fiber/100 g), $\geq 6$ skiver/dag

Grønnsaker, frukt og bær: $\geq 500 \mathrm{~g} / \mathrm{d}$, derav bær $\geq 150-200$ $\mathrm{g} /$ dag, frukt $\geq 175 \mathrm{~g} /$ dag og grønnsaker $\geq 175 \mathrm{~g} /$ dag

Matfett: Rapsolje. Rapsolje- og/eller solsikkeolje- og/eller soyaoljebaserte margariner til brødskivene

Meieriprodukter: Magre meieriprodukter $\leq 1 \%$ fett, ost $\leq 17 \%$ fett, unngå sukkerholdige yoghurter og melkeprodukter

Fisk: $\geq 3$ måltider/uke, derav 2 fete og 1 magert fiskemåltid

Kjøtt: Hovedsakelig hvitt kjøtt, kylling og vilt

Drikke: Ikke sukkerholdig drikke

Kosthold basert på 15 matvaregrupper, i hovedsak organisk dyrket med nordisk opprinnelse, basert på de nasjonale matvarebaserte kostholdsanbefalingene og de nordiske kostholdsanbefalingene (29). Deltagerne handlet inn gratis mat fra en forskningsbutikk, og en spesiallaget kokebok skulle brukes til matlagingen

Mer kalorier fra planter og mindre fra kjøtt: Belgfrukter, rotgrønnsaker, urter, poteter, fullkorn, frukt (epler, pærerl

Mer mat fra sjø og innsjø: Fisk, skalldyr, tang

Mer mat fra skogen/viltvoksende: Bær, nøtter, sopp, viltkjøtt

Det ble gitt råd om hva deltagerne skulle spise, og produkter ble utdelt

\section{Healthy diet group}

Kornprodukter: $\geq 20-25 \%$ av total energi ( $90 \%$ rugbrød), fullkornspasta ( $\geq 6 \mathrm{~g}$ fiber/100 gl 3,5 dl/uke

Fisk: 3 måltider/uke med fet fisk (100-150 g/porsjon)

Blåbær: 3 porsjoner/dag (totalt $300 \mathrm{~g} / \mathrm{dag}$ )

\section{Wholegrain enriched diet group}

Kornprodukter: $\geq 20-25 \%$ av total energi ( $90 \%$ rugbrød),

fullkornspasta ( $\geq 6 \mathrm{~g}$ fiber/100g) 3,5 dl/uke, fullkornkjeks

(1 porsjon/dag, 8-8,5 g fiber/100 g)

Fisk: Ikke endre vaner

Bær: Ikke endre vaner

\section{Kontrollkostholdsgruppen}

Oppfordret til å holde på sitt vanlige kosthold. Fikk ikke utdelt mat
Antall

deltagere Varighet Inklusjonskriterier

886 uker

Friske, 25-65 år,plasmaLDL-C $\geq 3,5 \mathrm{mmol} / \mathrm{l}, \mathrm{BM}$ $\geq 20 \mathrm{~kg} / \mathrm{m}^{2} \mathrm{og} \leq 31 \mathrm{~kg} / \mathrm{m}^{2}$ og hemoglobinkonsentrasjon $\geq 120 \mathrm{~g} / \mathrm{l}$ for kvinner $\circ \mathrm{g} \geq 130 \mathrm{~g} / \mathrm{l}$ for menn
Kostholdet var basert på data fra nasjonale kostholdsundersøkelser i Norden. Råd ble gitt for hva deltagerne kunne spise Enkelte produkter ble utdelt.

Kornprodukter: $\geq 25 \%$ av energien fra raffinerte produkter, derav $\geq 90 \%$ som hvete

Grønnsaker, frukt og bær: 200-250

$\mathrm{g} /$ dag, ingen blåbær

Matfett: Smør og andre melkefett-

baserte smørprodukter

Meieriprodukter: Ingen begrensninger

Fisk: $\leq 1 \mathrm{måltid} / \mathrm{uke}$

Kjøtt: Ingen begrensinger

Drikke: Ingen begrensninger

Kostholdet var basert på råvarer som kjennetegner danske matvaner fra nasjonale kostholdsundersøkelser Deltagerne handlet inn gratis mat fra en forskningsbutikk, og en spesiallaget kokebok med tradisjonelle danske matretter skulle brukes.

Raffinerte produkter av pasta og ris Grønnsaker med lite fiber og importert frukt (sitrus, bananer, melon)

Melkeprodukter og ost, sukkerholdige produkter

Råd ble gitt for hva deltagerne skulle spise, og produkter ble utdelt

Kornprodukter: Bytte ut vanlig brød med brød av huete $(3-4 \mathrm{~g}$ fiber $/ 100 \mathrm{~g}$ ) Pasta (< $6 \mathrm{~g}$ fiber/100 gl Maks 1-2 porsjoner med rugprodukter/dag

Fisk: Maks 1 måltid/uke

Bær: Ikke tillatt med blåbær og maks 3-4 porsjoner bær/uke (1 dl/porsjon)
181 26 uker for kvinner og $\geq 94 \mathrm{~cm}$ for menn. I tillegg ett eller flere av følgende kriterier:

Plasma-triglyseridkonsentrasjon $\geq 1,7 \mathrm{mmol} / \mathrm{l}$ HDL-C-konsentrasjon $\leq 1,03 \mathrm{mmol} / \mathrm{l}$ for menn, $\leq 1,29 \mathrm{mmol} / \mathrm{l}$ for kvinner. hypertensjon (systolisk/ diastolisk blodtrykk $>130 / 85 \mathrm{~mm} \mathrm{Hgl}$, svekket fastende glukose glukose 5,6-6,9 mmol/l eller nedsatt glukosetoleranse $7,8-11 \mathrm{mmol} / \mathrm{l}$ med oral glukosetest samt minst to av de følgende:

BMI $26-39 \mathrm{~kg} / \mathrm{m}^{2}$, livvidde $\geq 102 \mathrm{~cm}$ hos menn, $\geq 88 \mathrm{~cm}$ hos kvinner serum-triglyserol

$>1,7 \mathrm{mmol} / \mathrm{l}, \mathrm{HDL}-\mathrm{C}$ $<1,0 \mathrm{mmol} / \mathrm{l}$ hos menn og $<1,3 \mathrm{mmol} / \mathrm{l}$ hos kvinner og blodtrykk $\geq 130 / \geq 85 \mathrm{~mm} \mathrm{Hg}$ 


\section{Blodtrykk}

I tre av de fire intervensjonsstudiene ble det observert en signifikant reduksjon i blodtrykket etter inntak av nordisk kost. I SYSDIET-studien ble det ikke observert noen effekt på systolisk og diastolisk blodtrykk (15), men i en delstudie der kun deltagerne i Danmark ble inkludert, ble 24-timers diastolisk blodtrykk redusert med 3,7 mm $\mathrm{Hg}$ og gjennomsnittlig arterielt blodtrykk med $3,9 \mathrm{~mm}$ $\mathrm{Hg}$ hos de 37 individene med nordisk kosthold. I kontrollgruppen var det en økning på henholdsvis $0,8 \mathrm{~mm} \mathrm{Hg}$ og $0,4 \mathrm{~mm} \mathrm{Hg}$ på 24-timers diastolisk blodtrykk og gjennomsnittlig arterielt blodtrykk. Endringene var signifikant forskjellige i de to gruppene (henholdsvis $p=0,001$ og $p=0,006$ ) (16). Det var ingen effekt på systolisk blodtrykk.

I NORDIET-studien ble systolisk blodtrykk redusert med 6,55 $\mathrm{mm} \mathrm{Hg} \mathrm{hos} \mathrm{dem} \mathrm{med}$ nordisk kosthold, i kontrollgruppen økte det med $0,6 \mathrm{~mm} \mathrm{Hg}$. Forskjellen var signifikant forskjellig ( $p<0,008)$, men effekten forsvant når det ble justert for vektendring $\mathrm{i}$ gruppen med nordisk kosthold. I NND-studien ble systolisk og diastolisk blodtrykk redusert med henholdsvis $4,48 \mathrm{~mm} \mathrm{Hg}$ og 3,08 mm Hg. I kontrollgruppen økte systolisk og diastolisk blodtrykk med henholdsvis $0,72 \mathrm{~mm}$ $\mathrm{Hg}$ og $0,11 \mathrm{~mm} \mathrm{Hg}$. Endringene var signifikante $\mathrm{i}$ de to gruppene (henholdsvis $\mathrm{p}=0,001$ og $p=0,009)(18)$. Forandringen i systolisk blodtrykk i NND-gruppen forble signifikant etter justering for vekttap $(\mathrm{p}=0,041)$.

Det er holdepunkter for å anta at diastolisk blodtrykk muligens kan predikere mortaliteten for dem under 50 år (37). Den observerte blodtrykksreduksjonen i SYSDIETdelstudien kan derfor være viktig, resultatene tilsvarer resultatene i studier med middelhavskosthold $(38,39)$. I og med at kostholdet i SYSDIET-studien var isokalorisk og at deltagerne holdt stabil vekt, kan vekttap ikke være forklaringen på den observerte blodtrykksreduksjonen.

Det er vist at saltinntaket innvirker på blodtrykket (31). Forandringene i blodtrykk i SYSDIET-delstudien var ikke assosiert med forandringer i saltinntak. Dette tyder på at det er kombinasjonen av matvarer i det nordiske kostholdet som bidrar til den blodtrykksenkende effekten.

\section{Glukosemetabolisme og insulinsensitivitet}

I to av de fire intervensjonsstudiene ble det observert endringer i markører for glukoseog insulinsensitivitet. I NORDIET-studien ble insulinnivået redusert med $0,51 \mathrm{mU} / 1$, og insulinsensitiviteten, målt som HOMA-IR, ble redusert med 0,11 hos gruppen med et nordisk kosthold. I kontrollgruppen økte insulinnivået med 0,90 mU/1 og HOMA-IR økte med 0,22 . Endringene var signifikant forskjellig i de to gruppene (henholdsvis $\mathrm{p}=0,01$ og $\mathrm{p}=$ $0,01)$, men de forsvant når man justerte for vektendring.

I NND-studien ble nivået av fastende glukose redusert med henholdsvis $0,16 \mathrm{mmol} / 1$ og $0,05 \mathrm{mmol} / \mathrm{l}$ i gruppen med nordisk kosthold og i kontrollgruppen. Endringen var signifikant forskjellig $(\mathrm{p}=0,040)$, men denne forsvant når man justerte for vektendring (18). Dette tyder på at insulin- og glukosesensitiviteten i disse studiene først og fremst ble påvirket av vektendringen, og at endringer i kostholdet har mindre å si.

Resultatet samsvarer godt med funnet av manglende effekt på glukose- og insulinsensitivitet i SYSDIET- og SYSDIMET-studien, der deltagerne holdt en stabil vekt gjennom studieperioden $(15,19)$. I NND-studien ble det også utført plasma-metabolomanalyser (måling av alle typer metabolitter i plasma), som knyttet endringer i vekt og forbedret insulinsensitivitet til metabolske prosesser som økt ketose og økt glukoneogenese (23).

\section{Inflammasjon}

I tre av de fire intervensjonsstudiene ble det vist at et nordisk kosthold kan påvirke inflammasjonsmarkører. I SYSDIMET-studien (19) ble serumnivået av E-selektin signifikant redusert med et kosthold basert på fet fisk, blåbær og fullkorn $(p=0,04)$. Det var også en signifikant reduksjon i nivået av høysensitiv CRP (hsCRP) på $0,3 \mathrm{mg} / 1$ innad i gruppen som spiste fullkorn $(p=0,02)$. Forhøyede nivåer av hsCRP øker risikoen for hjerte- og karsykdom (40).

Hos deltakerne i SYSDIMET-studien var det også, hos dem som ikke brukte statiner, en sammenheng mellom økt inntak av fiber og marine omega-3-fettsyrer og redusert nivå av E-selektin. Det var en signifikant sammenheng mellom økt inntak av brød, i særlig grad rugbrød, og redusert nivå av hsCRP. Dette kan tyde på at marine omega3-fettsyrer og fiber kan være nøkkelfaktorer i et nordisk kosthold når det gjelder å dempe inflammasjon.

I SYSDIET-studien ble det observert en økning i inflammasjonsmarkøren IL-1Ra i gruppen med kontrollkosthold sammenlignet med intervensjonsgruppen $(\mathrm{p}<0,0001)$. Det var imidlertid ikke noen økning i andre inflammasjonsmarkører (15). IL-1Ra er regnet som en sensitiv markør for inflammasjon hos personer med overvekt og metabolsk syndrom. Det er vist at den predikerer debut av diabetes type 2 og progrediering fra metabolsk syndrom til diabetes type 2 (41-44). I SYSDIET-studien var det en assosiasjon mellom inntak av mettet fett og økt IL-1Ranivå (15).

For å få en bedre biologisk forståelse av fettvevets funksjon og kostholdets betydning for inflammasjon ble genuttrykk i fettvev studert i SYSDIET-studien (27). Resultatene viste at et nordisk kosthold gir redusert uttrykk av gener som koder for inflammasjonsmarkører. Disse resultatene er i tråd med resultatene $\mathrm{i}$ en studie på middelhavskosthold som viste at middelhavsmat kan modulere uttrykk av gener som koder for proaterogene faktorer i fettvev (45). I SYSDIET-studien ble uttrykket av inflammatoriske gener i perifere hvite blodceller etter en glukosetoleransetest redusert av et nordisk kosthold, men det et usikkert hvilken klinisk betydning dette har for utviklingen av metabolsk syndrom (26).

I NORDIET-studien var det signifikant forskjell $\mathrm{i}$ forandringene $\mathrm{i}$ cathepsin S-nivåene $i$ plasma mellom gruppene $(p=0,03)$ (14). Cathepsin S er et proteolytisk enzym som finnes i makrofager og glatte muskelceller i ateromatøse lesjoner i arterier. Økt nivå av cathepsin $\mathrm{S}$ i serum er knyttet til hjerte- og karsykdom, diabetes og inflammasjon, og nivået er økt i fettvev og serum hos overvektige individer $(46,47)$. Reduksjonen i cathepsin S var korrelert med vekttap, reduksjon i totalkolesterol- og LDL-kolesterolnivå, noe som kan tyde på at cathepsin S-nivået ikke er påvirket av kostholdet direkte.

\section{Diskusjon}

Et nordisk kosthold basert på myndighetenes kostråd og med nordiske matvarer påvirker flere viktige risikofaktorer for hjerte- og karsykdom. Effekten i reduksjon av kolesterolnivå og blodtrykk tilsvarer det som er sett med middelhavskosthold og andre tilsvarende kosthold (48).

I Norge og flere andre vestlige land har gjennomsnittsblodtrykket sunket siden 1980årene $(49,50)$, selv hos dem som ikke bruker blodtrykkssenkende medisiner og på tross av vektøkning. Årsaken er ikke kjent, men redusert inntak av salt og økt inntak av frukt og grønnsaker, som inneholder mye kalium, kan være av betydning - i tråd med funnene $\mathrm{i}$ denne oversiktsartikkelen. I tillegg viste noen av studiene at et sunt nordisk kosthold reduserer vekten, noe som igjen påvirker enkelte av risikofaktorene, deriblant insulin- og glukosesensitivitet. Hvorvidt effekten av et nordisk kosthold er like gunstig som effekten av et middelhavskosthold, vet man ikke, da det ennå ikke foreligger randomiserte, kontrollerte koststudier der man direkte sammenligner effekten av disse.

I en kostintervensjon er det en utfordring å bestemme hva kontrollgruppen skal spise. En svakhet ved tre av studiene er derfor at det ble gitt retningslinjer til kontrollgruppen som kan trekke deres kosthold i «usunn» retning - maksimum ett fiskemåltid i uken, bruk av smør og melkefett, grønnsaker med lite fiber, sukkerholdige produkter, ikke inntak av blåbær og restriksjoner på inntak av andre bær (tab 1). Dette trekker i retning av 
en forsterkning av observert intervensjonseffekt. Samtidig får man bedre frem betydningen av et nordisk kosthold basert på myndighetenes råd versus det å holde seg til «vanlig» kosthold.

Hjerte- og karsykdommer gir økt sykelighet og dødelighet, og legemidler til forebygging og behandling av disse sykdommene er av de mest solgte her til lands (51). Myndighetenes kostråd, gitt i den hensikt å bedre folkehelsen (12), innebærer konsum av matvarer tilsvarende det som er anbefalt $i$ de studiene som er oppsummert i denne artikkelen.

Alle studiene som er tatt med i denne oversiktsartikkelen, omhandler risikomarkører, ikke harde endepunkter. Derfor kan vi ikke si noe om effekten av et nordisk kosthold på forekomsten av sykdom eller eventuell prognose. Derimot er det vist at et middelhavskosthold gir redusert forekomst av hjerte- og karsykdom hos personer med risiko for utvikling av sykdom (3). Det vil derfor være av stor interesse å gjøre en tilsvarende studie i Norden med harde endepunkter for å kunne dokumentere om et nordisk kosthold basert på nordiske matvarer og myndighetenes kostråd har betydning for personer med risikofaktorer (tidlig sekundærprofylakse) og for hele befolkningen.

Gevinsten i form av bedre folkehelse er større ved en beskjeden kostholdsendring i gunstig retning hos hele befolkningen (primærprofylakse) enn ved målrettet intervensjon overfor pasienter og personer i en risikosituasjon. Av studiene som er beskrevet i denne artikkelen, var det kun i SYSDIETstudien man så på effekten av formidling av de nordiske kostholdsrådene. Det skjedde ved at kliniske ernæringsfysiologer ga råd om hvilke matvarer deltagerne skulle velge, i tillegg til utlevering av enkelte nøkkelmatvarer.

I en nyere norsk studie hvor noen få kommersielt tilgjengelige matvarer ble byttet ut med tilsvarende produkter med bedre fettsyresammensetning (høyere andel flerumettet fett) $i$ åtte uker, ble det vist klinisk relevante endringer i total- og LDL-kolesterolnivå med små endringer $i$ det daglige kostholdet (52). Forskjellen i LDL-kolesterolnivå var identisk med den man så i Improve-it-studien, der man testet effekten av ezetimib på toppen av statinbehandling (53). Det viser at kostendringer er like effektivt som tilleggsmedikasjon for dem som får statinbehandling. Det er derfor viktig at leger sammen med kliniske ernæringsfysiologer formidler denne kunnskapen og motiverer pasienter til å spise i henhold til myndighetenes kostråd.

Ved å holde seg til et nordisk kosthold med nordiske råvarer som er lett tilgjengelige og godt kjent, kan mat være god medisin.

\section{Astrid Berild (f. 1987)}

var medisinstudent ved Universitetet i Oslo, nå turnuslege ved Drammen sykehus. Forfatter har fylt ut ICMJE-skjemaet og oppgir ingen interessekonflikter.

\section{Kirsten B. Holven (f. 1963)}

er ernæringsfysiolog, professor i klinisk ernæring og seksjonsleder.

Forfatter har fylt ut ICMJE-skjemaet og oppgir følgende interessekonflikter: Hun har mottatt bidrag fra Mills, TINE, Amgen, Olympic Seafood, Sanofi og Pronova.

\section{Stine M. Ulven (f. 1970)}

er ernæringsfysiolog og professor i ernæring Hun er partner i et nordisk senter for fremragende forskning innen mat, ernæring og helse, kalt SYSDIET, som har som hovedmål å studere helseeffekter av nordisk kosthold. Mye av den henviste litteraturen i dette manuskriptet er hentet fra SYSDIET-studien. Forfatter har fylt ut ICMJE-skjemaet og oppgir følgende interessekonflikter: Hun har mottatt bidrag fra Mills, TINE og Olympic seafood.

\section{Litteratur}

1. Selmer R, Hovda GE, Iversen S-G et al. Hjerteog karsykdommer i Norge. Folkehelserapporten 2014. Oslo: Folkehelseinstituttet, 2014 https://fhi.no/nettpub/helse-og-sykdom/hierte-og-karsykdommer-i-norge---f/ (23.3.2017).

2. World Health Organization and Ebooks Corporation. World Health Statistics 2015. Genève: WHO, 2015

3. Estruch R, Ros E, Salas-Salvadó J et al. Primary prevention of cardiovascular disease with a Mediterranean diet. N Engl J Med 2013; 368: 1279-90. 4. de Lorgeril M, Renaud S, Mamelle N et al. Mediterranean alpha-linolenic acid-rich diet in secondary prevention of coronary heart disease. Lancet 1994; 343: 1454-9.

5. Esposito K, Kastorini CM, Panagiotakos DB et al. Mediterranean diet and metabolic syndrome: an updated systematic review. Rev Endocr Metab Disord 2013; 14: 255-63.

6. Shen J, Wilmot KA, Ghasemzadeh N et al. Mediter ranean Dietary Patterns and Cardiovascular Health. Annu Rev Nutr 2015: 35: 425-49.

7. Papadaki A, Scott JA. The impact on eating habits of temporary translocation from a Mediterranean to a Northern European environment. Eur J Clin Nutr 2002; 56: 455-61.

8. Roininen K, Tuorila H, Zandstra EH et al. Differences in health and taste attitudes and reported behaviour among Finnish, Dutch and British consumers: a cross-national validation of the Health and Taste Attitude Scales (HTAS). Appetite 2001; 37: $33-45$.

9. Mackenbach JP. The Mediterranean diet story illustrates that «why» questions are as important as «how» questions in disease explanation. J Clin Epidemiol 2007; 60: 105-9

10. Pretty JN, Ball AS, Lang T et al. Farm costs and food miles: an assesment of the full cost of the UK weekly food basket. Food Policy 2005; 30: 1-19.

11. Bere E, Brug J. Towards health-promoting and environmentally friendly regional diets - a Nordic example. Public Health Nutr 2009; 12: 91-6.

12. Helsedirektoratet. Kostråd. https://helsedirektoratet.no/publikasjoner/kostradfor-a-fremme-folkehelsen-og-forebygge-kroniskesykdommer-metodologi-og-vitenskapeligkunnskapsgrunnlag (23.3.2017).
13. Adamsson V, Reumark A, Fredriksson IB et al. Effects of a healthy Nordic diet on cardiovascular risk factors in hypercholesterolaemic subjects: a randomized controlled trial (NORDIET). J Intern Med 2011; 269: 150-9

14. Jobs E, Adamsson V, Larsson A et al. Influence of a prudent diet on circulating cathepsin $\mathrm{S}$ in humans. Nutr J 2014: 13: 84

15. Uusitupa M, Hermansen K, Savolainen MJ et al. Effects of an isocaloric healthy Nordic diet on insulin sensitivity, lipid profile and inflammation markers in metabolic syndrome - a randomized study (SYSDIET). J Intern Med 2013; 274: 52-66.

16. Brader L, Uusitupa M, Dragsted LO et al. Effects of an isocaloric healthy Nordic diet on ambulatory blood pressure in metabolic syndrome: a randomized SYSDIET sub-study. Eur J Clin Nutr 2014; 68: $57-63$

17. Lankinen $M$, Kolehmainen $M$, Jääskeläinen $T$ et al. Effects of whole grain, fish and bilberries on serum metabolic profile and lipid transfer protein activities: a randomized trial (Sysdimet). PLoS One 2014; 9: e90352.

18. Poulsen SK, Due A, Jordy AB et al. Health effect of the New Nordic Diet in adults with increased waist circumference: a 6-mo randomized controlled trial. Am J Clin Nutr 2014; 99: 35-45.

19. de Mello VD, Schwab U, Kolehmainen M et al. A diet high in fatty fish, bilberries and wholegrain products improves markers of endothelial function and inflammation in individuals with impaired glucose metabolism in a randomised controlled trial: the Sysdimet study. Diabetologia 2011; 54 2755-67.

20. Lankinen M, Schwab U, Kolehmainen M et al. Whole grain products, fish and bilberries alter glucose and lipid metabolism in a randomized, controlled trial: the Sysdimet study. PLoS One 2011; 6 : e22646.

21. Poulsen SK, Crone C, Astrup A et al. Long-term adherence to the New Nordic Diet and the effects on body weight, anthropometry and blood pressure: a 12-month follow-up study. Eur J Nutr 2015; 54: 67-76.

22. Adamsson V, Cederholm T, Vessby B et al. Influence of a healthy Nordic diet on serum fatty acid composition and associations with blood lipoproteins - results from the NORDIET study. Food Nutr Res 2014: 58: 24114

23. Khakimov B, Poulsen SK, Savorani F et al. New Nordic Diet versus Average Danish Diet: A Randomized Controlled Trial Revealed Healthy LongTerm Effects of the New Nordic Diet by GC-MS Blood Plasma Metabolomics. J Proteome Res 2016; 15: 1939-54

24. Marklund M, Magnusdottir OK, Rosqvist F et al. A dietary biomarker approach captures compliance and cardiometabolic effects of a healthy Nordic diet in individuals with metabolic syndrome. J Nutr 2014; 144: 1642-9.

25. Lankinen M, Schwab U, Kolehmainen M et al. A Healthy Nordic Diet Alters the Plasma Lipidomic Profile in Adults with Features of Metabolic Syndrome in a Multicenter Randomized Dietary Intervention. J Nutr 2016; jn220459. E-publisert 9.3.2016.

26. Leder L, Kolehmainen M, Narverud I et al. Effects of a healthy Nordic diet on gene expression changes in peripheral blood mononuclear cells in response to an oral glucose tolerance test in subjects with metabolic syndrome: a SYSDIET substudy. Genes Nutr 2016: 11: 3

27. Kolehmainen M, Ulven SM, Paananen J et al. Healthy Nordic diet downregulates the expression of genes involved in inflammation in subcutaneous adipose tissue in individuals with features of the metabolic syndrome. Am J Clin Nutr 2015: 101 : 228-39.

28. Adamsson V, Reumark A, Cederholm T et al. What is a healthy Nordic diet? Foods and nutrients in the NORDIET study. Food Nutr Res 2012; 56: 18189

29. Mithril C, Dragsted LO, Meyer C et al. Dietary composition and nutrient content of the New Nordic Diet. Public Health Nutr 2013; 16: 777-85. 
30. Wilson PWF. Overview of the risk equivalents and established risk factors for cardiovascular diseases. Uptodate 2015. www.uptodate.com/contents/ overview-of-the-risk-equivalents-and-establishedrisk-factors-for-cardiovascular-disease? source= machineLearning\&search=Cardiovascular+ disease+and+risk+factors\&selectedTitle=1\%7E150 \&sectionRank=1\&anchor $=\mathrm{H} 2$ (25.8.2015)

31. Diet, Nutrition and the Prevention of Chronic Diseases: report of a joint WHO/FAO expert consultation. Report No. 916 WHO technical report series. Genève: WHO, 2002

32. Rosenson R. Statins: actions, side effects and administration. Uptodate 2015. www.uptodate. $\mathrm{com} /$ contents/statins-actions-side-effects-andadministration?source=machine Learning \& search $=$ Statins + and $+L D L+$ reduction \& selected Title $=1 \% 7 \mathrm{E} 150$ \& sectionRank $=2 \&$ anchor $=\mathrm{H} 30$ (28.9.2015).

33. Rhee EP, Cheng S, Larson MG et al. Lipid profiling identifies a triacylglycerol signature of insulin resistance and improves diabetes prediction in humans. J Clin Invest 2011; 121: 1402-11.

34. Njølstad I, Mathiesen EB, Schirmer H et al. The Troms $\varnothing$ study 1974-2016: 40 years of cardiovascular research. Scand Cardiovasc J 2016: 50 276-81.

35. Barter PJ, Caulfield M, Eriksson M et al. Effects of torcetrapib in patients at high risk for coronary events. N Engl J Med 2007: 357: 2109-22.

36. Schwartz GG, Olsson AG, Abt M et al. Effects of dalcetrapib in patients with a recent acute coronary syndrome. N Engl J Med 2012; 367: 2089-99.

37. Basile J, Block M. Overview of hypertension in adults. Uptodate 2015. www.uptodate.com/ contents/overview-of-hypertension-in-adults? source=see_link \&sectionName=DEFINITIONS\& anchor $=\mathrm{H}_{2}$ (9.9.2015).

38. Estruch R, Martínez-González MA, Corella D et al. Effects of a Mediterranean-style diet on cardiovas- cular risk factors: a randomized trial. Ann Intern Med 2006: 145: 1-11.

39. Kastorini CM, Milionis HJ, Esposito K et al. The effect of Mediterranean diet on metabolic syndrome and its components: a meta-analysis of 50 studies and 534,906 individuals. J Am Coll Cardiol 2011; 57: 1299-313

40. Morrow D. Screening for cardiovascular risk with C-reactive protein. Uptodate 2015. www.uptodate. com/contents/screening-for-cardiovascular-riskwith $-c$-reactive - protein? source=machineLearning \&search=Cardiovascular + disease + and + CRP\& selectedTitle $=2 \% 7 E 150 \&$ sectionRank $=2 \&$ anchor= H4 (9.9.2015).

41. Festa A, Hanley AJ, Tracy RP et al. Inflammation in the prediabetic state is related to increased insulin resistance rather than decreased insulin secretion. Circulation 2003; 108: 1822-30.

42. Salmenniemi U, Ruotsalainen E, Pihlajamäki J et al. Multiple abnormalities in glucose and energy metabolism and coordinated changes in levels of adiponectin, cytokines, and adhesion molecules in subjects with metabolic syndrome. Circulation 2004; 110: 3842-8.

43. Carstensen M, Herder C, Kivimäki M et al. Accelerated increase in serum interleukin-1 receptor antagonist starts 6 years before diagnosis of type 2 diabetes: Whitehall II prospective cohort study. Diabetes 2010; 59: 1222-7.

44. Herder C, Brunner EJ, Rathmann W et al. Elevated levels of the anti-inflammatory interleukin-1 receptor antagonist precede the onset of type 2 diabetes: the Whitehall II study. Diabetes Care 2009; 32 : 421-3

45. Llorente-Cortés V, Estruch R, Mena MP et al. Effect of Mediterranean diet on the expression of pro-atherogenic genes in a population at high cardiovascular risk. Atherosclerosis 2010; 208: 442-50.

46. Naour N, Rouault C, Fellahi S et al. Cathepsins in human obesity: changes in energy balance predominantly affect cathepsin $\mathrm{s}$ in adipose tissue and in circulation. J Clin Endocrinol Metab 2010: 95 $1861-8$.

47. Taleb S, Lacasa D, Bastard JP et al. Cathepsin S, a novel biomarker of adiposity: relevance to atherogenesis. FASEB J 2005; 19: 1540-2.

48. Ndanuko RN, Tapsell LC, Charlton KE et al. Dietary Patterns and Blood Pressure in Adults: A Systematic Review and Meta-Analysis of Randomized Controlled Trials. Adv Nutr 2016; 7: 76-89.

49. Holmen J, Holmen TL, Tverdal A et al. Blood pressure changes during 22-year of follow-up in large general population - the HUNT Study, Norway. BMC Cardiovasc Disord 2016; 16: 94.

50. Hopstock LA, Bønaa KH, Eggen AE et al. Longitudinal and Secular Trends in Blood Pressure Among Women and Men in Birth Cohorts Born Between 1905 and 1977: The Tromsø Study 1979 to 2008. Hypertension 2015; 66: 496-501.

51. Legemiddelforbruk i Norge. Oslo: Folkehelseinstituttet, 2013. www.fhi.no/tema/legemidler/ legemiddelbruk (9.9.2015)

52. Ulven SM, Leder L, Elind E et al. Exchanging a few commercial, regularly consumed food items with improved fat quality reduces total cholesterol and LDL-cholesterol: a double-blind, randomised controlled trial. Br J Nutr 2016; 116: 1383-93.

53. Cannon CP, Blazing MA, Giugliano RP et al. Ezetimibe Added to Statin Therapy after Acute Coronary Syndromes. N Engl J Med 2015; 372: 2387-97.

Mottatt 14.3. 2016, første revisjon innsendt 4.9. 2016, godkjent 22.2. 2017. Redaktør: Tor Rosness. 